Journal of Engineering and Applied Sciences 14 (Special Issue 7): 10156-10161, 2019

ISSN: 1816-949X

(C) Medwell Journals, 2019

\title{
An Engineering Study of a Soil for Residential Project in Karbala Province
}

\author{
Amer Atiya Al-Khalidi and Ahmed Qasem Mahmood \\ College of Sciences, University of Babylon, Hillah, Iraq
}

\begin{abstract}
This research is included studying the physical, chemical and engineering features for the soil in the research area through digging three wells of $20 \mathrm{~m}$ depth and taking samples for testing. The study aims to make a geotechnical evaluation and calculating the bearing capacity of the soil in the research area. Depending on the results of the analyzation and using the Unified Soil Classification System (USCS), its clear that the soil is coarse granules one and sandy, the percentage of sand is about $52-77 \%$, the clay is between $2-45 \%$, silt 17-28\%, Liquid Limit (LL) is 24-39\%, Plasticity Index (PI) is 13-21\%, water content is 6.5-26.7\%, permeability is $6.22 \times 10^{-3}$ to $1.37 \times 10^{-6} \mathrm{~cm} / \mathrm{sec}$, bearing capacity by dynamic method is $6.9-41.15 \mathrm{~T} / \mathrm{m}^{2}$ and by static method is $10.68 \mathrm{~T} / \mathrm{m}^{2}$ of $1 \mathrm{~m}$ depth and is $16.30 \mathrm{Tm}^{2}$ of $4 \mathrm{~m}$ depth. The soil cohesive values are equal $0-0 \mathrm{~T} / \mathrm{m}^{2}$, values of internal friction angles are $16-41^{\circ}$. A chemical analyzation for the soil and ground water in the research area is made. Results show that ground water has weak basicity and the percentage of salts is high, the water has Sulfate content $\left(\mathrm{SO}_{3}\right)$ which is about $1225-1218 \mathrm{ppm}$. The results of the chemical tests of the soil also show that sulfate content is about $4.55-9.11 \%$ for different depth, the percentage of the organic matter of the soil is (1.58-0.26\%), total soluble salttest is $31.13-16.45 \%$ and the gypsum content is $9.77-19.58 \%$.
\end{abstract}

Key words: Geotechnical, bearing capacity, Karbala, plasticity index, chemical, analyzation

\section{INTRODUCTION}

The geotechnical study is one of the important geological studies because it specifies the engineering behavior for soil materials and the capacity of bearing soil on which the residential projects are built Fig. 1. The engineering geology is considered as a key factor inidentifying the site of any project specifically the big

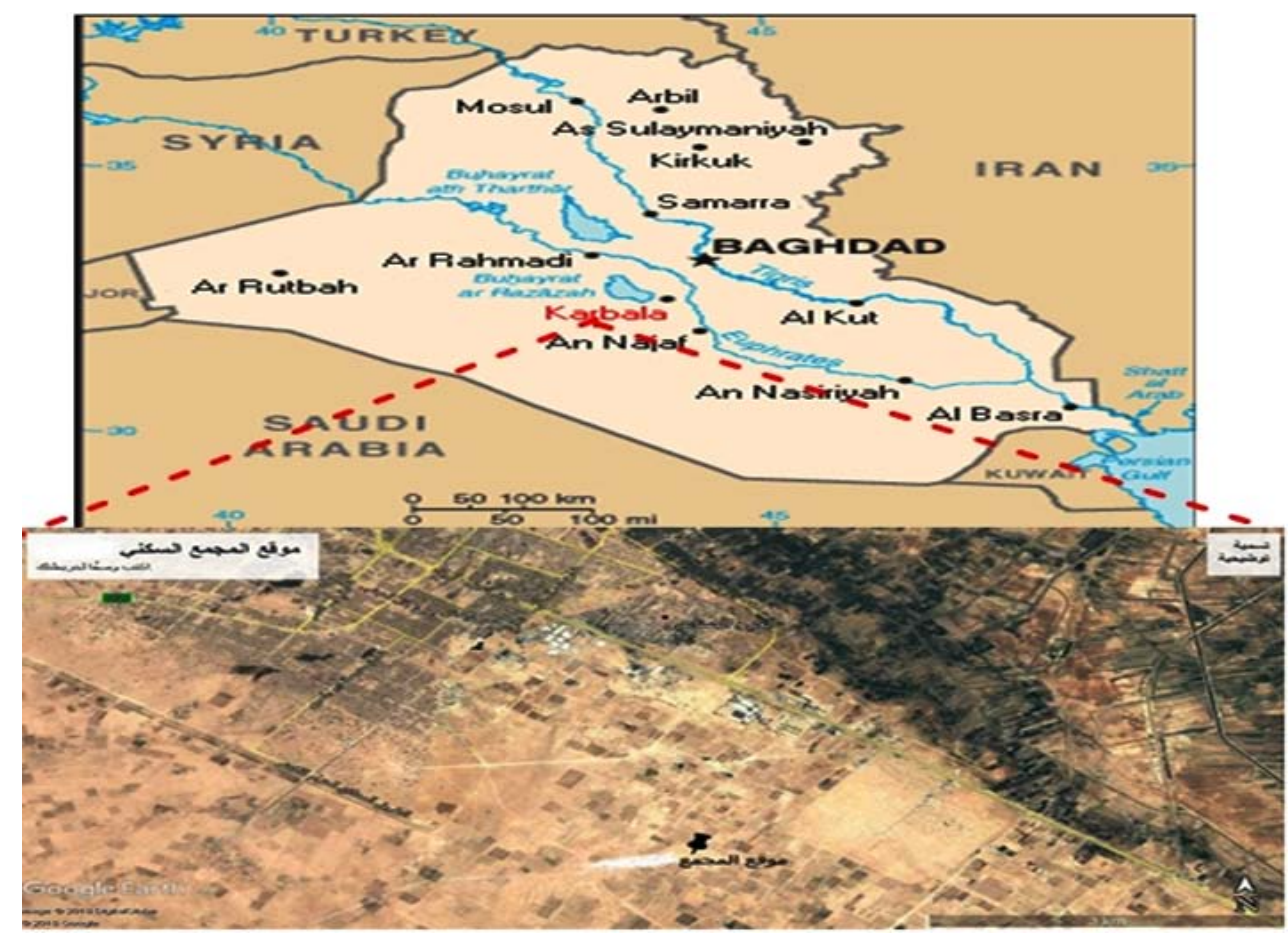

Fig. 1: The map of Iraq and the location of Karbala province and satellite image of the study site 
engineering projects or strategic projects like the site of cities (Abood et al., 2016). The geotechnical evaluation includes studying the soil physical and engineering features like pressures on soil including consolidation and confined compressive, the chemical status of soilis to show the existence of salts in it which effects the physical and engineering features (Bowles, 1979). Digging is the best way in the underground geological studies (Lafta et al., 2015). So, we make this study to identify the engineering behavior of the soil when different pressures are put on it to specify the engineering problems and find suitable solutions to avoid risks if the soil is inappropriate of establishing an engineering project on it. In Iraq, the soil is different and changeable from the geological or engineering side and the reason behind that belongs to the way of forming the soil and hereditary relation between the soil basic contents and the stones of the base in addition to different factors like earthmoving and the different effects of climate factors from one area to another (Thabet et al., 1993). The soil is considered as an example of inconsistent system that are made by many stages and granules of different features (Al-Khalidy et al., 2009). The geological evaluation is considered one of the important factors that play a key role in the constructional works, especially, those which includes the different treatments for soil that contribute in suggest the designs that are suitable for the project needs (AL-Jabban, 2014).

Location of the study area: The location is in the South of Karbala city center $100 \mathrm{~km}$ South of Baghdad. It is a future project to build residentialcomplexes of various floors Fig. 1.

The area is tectonic from the geological side and it belongs to Mesopotamian zone or as it is called sedimentary zone which is unfolded. It is unstable shelf zone (Buday and Jassim, 1987). The study area is covered with alluvial environment of Euphrates and some of transported deposits by winds. The existed sediments are clay, silts and sand (Jassim and Goff, 2006).

\section{MATERIALS AND METHODS}

Field work: Three tested wells are dug in the study area by using flight auger machine according to the American Standards (ASTM D-1452-D5783) for the period from
(2-1-2019/7-1-2019). The depth of each well is $20 \mathrm{~m}$ of the Natural Ground Surface (NGS). Two samples are taken.

Disturbed sample which is taken according to the American Standards (ASTM D-1587), samples are taken from the digger pillar which are disturbed. Split spoon sample which is got by Standard Penetration Test (SPT) is also disturbed sample and taken by samples collector. We can't get the undisturbed samples because of the coarse granules soil (sandy soil) in general, as shown in appendix 1-3, the samples are notated and kept in plastic bags and taken to the lab for making the required tests. Standard Penetration Test (SPT) is done and it is one of the fields tests and considered as one of the important dynamic test which is done in the site. This test is done according to the American Standards (ASTM D-1586-99). We can make use of calculating the number of (N-vales) in identifying the relative density of the soil. If the (N-vales) are few, the soil will be loose and if the ( $\mathrm{N}$-vales) is big, the soil will be very dense (Al-Asho and Mohammed, 1997).

The calculated (N-vales) in each well in the study area (B.H 1-3) in the different depths are 39-50/6 which means that the soil is very dense as shown in Table 1. The water table level is between $7-12 \mathrm{~m}$ which is identified $24 \mathrm{~h}$ of each well digging (Bowles, 1979).

\section{Laboratory work; it includes labs tests on the samples as follow Classification of soil:}

- Moisture content

- Grain size analysis

- Atterberge limits

- Engineering test

- Direct shear test

\section{Chemical tests; in percentage:}

- $\quad$ Sulphate test $\left(\mathrm{SO}_{3} \%\right)$

- Total soluble salt test (\%)

- Gypsum (\%)

- Carbonates $\left(\mathrm{CaCO}_{3} \%\right)$

- Chlorides (Cl\%)

- Organic matter (\%)

Table 1: Water table level

\begin{tabular}{|c|c|c|c|c|c|}
\hline The date of measurement & Under ground water elevation (m) from drilling & Bored method & Bored depth (m) & Bored diameter (m) & BH No. \\
\hline \multirow{3}{*}{ January-2019 } & 7.0 & Flight augers & 20 & 0.10 & 1 \\
\hline & 12.5 & & 20 & 0.10 & 2 \\
\hline & 12.0 & & 20 & 0.10 & 3 \\
\hline
\end{tabular}


J. Eng. Applied Sci., 14 (Special Issue 7): 10156-10161, 2019

Table 2: Shows (N-vales) and relative density (Bowles,1984)

\begin{tabular}{llc}
\hline Relative density & SPT N & Angle of internal friction (degrees) \\
\hline Very loose & More than 4 & More than 30 \\
Loose & $4-10$ & $30-35$ \\
Medium dense & $10-30$ & $35-40$ \\
Dense & $30-50$ & $40-45$ \\
Very dense & $<50$ & $<45$ \\
\hline
\end{tabular}

Table 3: Allowable bearing capacity of the soil from N-SPT method

\begin{tabular}{|c|c|c|c|c|c|c|}
\hline Depth (m) & $\begin{array}{l}\text { SPT(N) total } \\
\text { for } 300 \mathrm{~mm} \mathrm{BH} 1\end{array}$ & $\begin{array}{l}\text { SPT(N) total for } \\
300 \mathrm{~mm} \mathrm{BH} 2\end{array}$ & $\begin{array}{l}\text { SPT(N) Total for } \\
300 \mathrm{~mm} \mathrm{BH3}\end{array}$ & $\begin{array}{l}\text { Average SPT(N) total } \\
\text { for } 300 \mathrm{~mm}\end{array}$ & $\begin{array}{l}\mathrm{NC}=\text { correction average } \\
\mathrm{SPT}(\mathrm{N}) \text { total for } 300 \mathrm{~mm}\end{array}$ & $\begin{array}{c}\text { Ave. BC } \\
\mathrm{T}^{\prime} \mathrm{M}^{2} \\
\end{array}$ \\
\hline 1.5 & 57 & 39 & 61 & 52 & 33.5 & 6.9 \\
\hline 2.0 & - & 50 & 62 & 56 & 35.5 & 7.8 \\
\hline 3.0 & $50 / 6^{\prime \prime}$ & - & 82 & 91 & 53 & 13.07 \\
\hline 4.0 & - & 68 & - & 68 & 41.5 & 11.36 \\
\hline 5.0 & 58 & - & 88 & 73 & 44 & 13.25 \\
\hline 6.0 & $50 / 5^{\prime \prime}$ & - & $50 / 4^{\prime \prime}$ & $50 / 5^{\prime \prime}$ & 58 & 19.04 \\
\hline 7.0 & - & $50 / 5^{\prime \prime}$ & 85 & 93 & 54 & 19.20 \\
\hline 8.0 & - & $50 / 4^{\prime \prime}$ & $50 / 4^{\prime \prime}$ & $50 / 4^{\prime \prime}$ & 58 & 22.20 \\
\hline 9.0 & $50 / 5^{\prime \prime}$ & $50 / 5^{\prime \prime}$ & - & 50/5" & 58 & 23.78 \\
\hline 10.0 & $50 / 4^{\prime \prime}$ & 92 & - & 96 & 55.5 & 22.37 \\
\hline 11.0 & $50 / 4^{\prime \prime}$ & - & 88 & 94 & 54.5 & 21.40 \\
\hline 12.0 & - & $50 / 5^{\prime \prime}$ & $50 / 5^{\prime \prime}$ & $50 / 5^{\prime \prime}$ & 58 & 28.51 \\
\hline 13.0 & $50 / 6^{\prime \prime}$ & 96 & & 95 & 55 & 28.54 \\
\hline 14.0 & $50 / 6^{\prime \prime}$ & - & $50 / 4^{\prime \prime}$ & $50 / 5^{\prime \prime}$ & 58 & 31.6 \\
\hline 15.0 & - & $50 / 5^{\prime \prime}$ & $50 / 3^{\prime \prime}$ & $50 / 4^{\prime \prime}$ & 58 & 33.25 \\
\hline 16.0 & $50 / 4^{\prime \prime}$ & $50 / 4^{\prime \prime}$ & - & $50 / 4^{\prime \prime}$ & 58 & 34.83 \\
\hline 17.0 & $50 / 3^{\prime \prime}$ & - & $50 / 4^{\prime \prime}$ & $50 / 4^{\prime \prime}$ & 58 & 36.41 \\
\hline 18.0 & $50 / 3^{\prime \prime}$ & $-50 / 5^{\prime \prime}$ & - & $50 / 4^{\prime \prime}$ & 58 & 37.99 \\
\hline 19.0 & - & $50 / 4^{\prime \prime}$ & $50 / 4^{\prime \prime}$ & $50 / 4^{\prime \prime}$ & 58 & 39.57 \\
\hline 20.0 & $50 / 5^{\prime \prime}$ & 91 & 93 & 96 & 58 & 41.15 \\
\hline
\end{tabular}

\section{RESULTS AND DISCUSSION}

American and/British standards (ASTM\&B.S) are used in making tests of samples of the study area, the results are as follow:

\section{Physical properties of the soil in the study}

Grain size analysis: This analysis is considered as the corner stone in the soil classification and to conclude the soil features (Bowles, 1984), the test is done according to the American standards (ASTM D-421-422), results are shown in appendix 1-3, from the testing results by using USCS, it is clear that the soil is coarse granules as porly to well graded sand (SP to SW), to pore graded sand with silt (SP to SM), to silty Sand (SM), to Clay Sand (SC). From the other side, there are pockets for cohesive soil of different depths for some wells and described as clay silt of low to high plasticity (ML to $\mathrm{MH}$ ). The sequence of layers in the wells are silty sand/silty clay sand except the well $(\mathrm{BH} 3)$ in depth $\left(10.5-^{13} \mathrm{~m}\right)$ is silty sandy Clay (CL) (Bell, 1994) Table 2 and 3.

Atterberge limits: They give an impression whether the soil will be opposed to shrinkage or swelling. After comparison their normal moisture with plasticity limit and shrinkage limit, they are also important in soil classification (Chen, 2000). The engineering use of Atterberge limits is to control the soil used in filling and empirical methods in $t$ he engineering design (Al-Khalidy et al., 2009). The test is done due to the
Table 4: Strength parameters (unconfined and triaxle test and direct shear test results with depth

\begin{tabular}{|c|c|c|c|c|c|}
\hline \multirow[b]{2}{*}{ BH. (No) } & \multirow[b]{2}{*}{ Depth (m) } & \multicolumn{2}{|c|}{ Direct shear test } & \multirow[b]{2}{*}{$\begin{array}{c}\gamma_{\text {wet }} \\
\left.\mathrm{gm} / \mathrm{c} \mathrm{m}^{3}\right)\end{array}$} & \multirow[b]{2}{*}{$\begin{array}{c}\gamma_{\text {dry }} \\
\mathrm{gm} / \mathrm{cm}\end{array}$} \\
\hline & & $\begin{array}{l}\text { Drained } \\
\mathrm{C} \mathrm{T} / \mathrm{m}^{2}\end{array}$ & $\begin{array}{l}\text { Drained } \\
(\varnothing)\end{array}$ & & \\
\hline \multirow[t]{6}{*}{$\mathrm{BH} 1$} & $2-2.5$ & 0.00 & 34 & 1.85 & 1.83 \\
\hline & $4.5-5$ & 0.00 & 35 & 2.60 & 2.05 \\
\hline & $7-7.5$ & 2.79 & 22 & 2.17 & 2.15 \\
\hline & $10-10.5$ & 3.48 & 19 & 2.13 & 1.76 \\
\hline & $13-13.5$ & 3.25 & 21 & 2.11 & 1.69 \\
\hline & $16.5-17$ & 0.00 & 41 & 2.15 & 1.73 \\
\hline \multirow[t]{6}{*}{$\mathrm{BH} 2$} & $1.5-2$ & 0.00 & 30 & 1.85 & 1.84 \\
\hline & $4.5-5$ & 0.00 & 34 & 1.98 & 1.96 \\
\hline & $7.5-8$ & 2.94 & 20 & 2.13 & 2.11 \\
\hline & $10.5-11$ & 0.00 & 37 & 2.06 & 1.65 \\
\hline & $13.5-14$ & 0.00 & 34 & 2.16 & 1.73 \\
\hline & $16.5-17$ & 3.82 & 16 & 2.17 & 1.74 \\
\hline \multirow[t]{5}{*}{$\mathrm{BH} 3$} & $1-1.5$ & 0.00 & 35 & 1.98 & 1.95 \\
\hline & $3-3.5$ & 0.00 & 37 & 1.85 & 1.83 \\
\hline & $6-6.5$ & 0.00 & 41 & 2.60 & 2.5 \\
\hline & $9.5-10$ & 2.97 & 20 & 2.13 & 1.78 \\
\hline & $15-15.5$ & 0.00 & 37 & 2.20 & 1.77 \\
\hline
\end{tabular}

Table 5: Allowable bearing capacity with depth $\overline{\mathrm{Df}=\text { The depth of foundation }(\mathrm{m}) \quad \text { Allowable bearing capacity }\left(\mathrm{T} / \mathrm{m}^{2}\right)}$

\begin{tabular}{ll}
\hline 1.0 & 10.68 \\
2.0 & 12.57 \\
3.0 & 14.38 \\
4.0 & 16.30 \\
\hline
\end{tabular}

American standards (ASTM D4318), the results of Liquid Limit (LL), Plasticity Limit (PL) and Plasticity Index as shown in appendix 1-3 are between (24-39\%) for LL and (13-21\%) for PI Table 4 and 5. 
J. Eng. Applied Sci., 14 (Special Issue 7): 10156-10161, 2019

Table 6: Results of chemical analysis for soil

\begin{tabular}{|c|c|c|c|c|c|c|c|c|}
\hline No. of BH & Depth (m) & $\mathrm{SO}_{3}(\%)$ & Gypsom (\%) & TSS (\%) & ORG (\%) & $\mathrm{CaCO}_{3}(\%)$ & $\mathrm{pH}(\%)$ & $\mathrm{Cl}(\%)$ \\
\hline \multirow[t]{4}{*}{$\overline{\mathrm{BH} 1}$} & $1.5-2$ & 9.11 & 19.58 & 31.31 & 1.58 & 17.0 & 7.8 & 0.048 \\
\hline & $2-2.5$ & 8.74 & 18.77 & 29.43 & 1.21 & 19.0 & 7.9 & 0.045 \\
\hline & 3-3.5 & 5.57 & 11.96 & 21.55 & 0.92 & 21.1 & 7.9 & 0.042 \\
\hline & $4.5-5$ & 7.89 & 19.95 & 29.22 & 0.71 & 24.0 & 8.1 & 0.037 \\
\hline \multirow[t]{4}{*}{ BH2 } & $5.5-6$ & 5.71 & 12.27 & 20.39 & 0.64 & 28.0 & 7.8 & 0.034 \\
\hline & $6.5-7$ & 5.97 & 12.82 & 21.20 & 0.48 & 27.0 & 7.9 & 0.032 \\
\hline & 7.5-8 & 7.33 & 15.76 & 23.21 & 0.43 & 29.0 & 7.9 & 0.029 \\
\hline & $8.5-9$ & 7.50 & 16.11 & 26.32 & 0.36 & 33.0 & 8.0 & 0.028 \\
\hline \multirow[t]{3}{*}{ BH3 } & $10-10.5$ & 4.76 & 10.22 & 17.53 & 0.28 & 36.0 & 7.9 & 0.024 \\
\hline & $12-12.5$ & 4.55 & 9.77 & 16.45 & 0.26 & 34.0 & 8.0 & 0.019 \\
\hline & $13-13.5$ & 4.82 & 10.35 & 18.37 & - & 38.0 & - & - \\
\hline
\end{tabular}

Table 7: Chemical analysis for ground water

\begin{tabular}{|c|c|c|c|c|c|c|}
\hline $\mathrm{SO}_{4}(\mathrm{mg} / \mathrm{L})$ & CL (mg/L) & $\mathrm{pH}$ & EC*10 (mmhos/cm) & TDS (mg/L) & Depth water (m) & BH No. \\
\hline 1218 & 582 & 7.9 & 1.22 & 4739 & 7 & 1 \\
\hline 1221 & 585 & 7.8 & 1.26 & 4744 & 12.5 & 2 \\
\hline 1225 & 583 & 7.9 & 1.25 & 4742 & 12 & 3 \\
\hline
\end{tabular}

Water content: Water has two effects on the soil: the first is that water forms pressure among the soil granules, especially, the clay soil while the second is that it forms pore pressure which effects the soil (Yasin, 1990). The soil plasticity is no more an indicator of water content and the controlling of the soft parts of soil has a great role in changing the physical features by changing water content.

The lab test of samples has been done according to the American standards (ASTM-D 2216), results show that soil water content is little (between 6.5-26.7) as shown in appendix 1 (Lambe and Whitman, 1969).

Permeability: It is foundfor samples according to the American standards (ASTM-D-2434) by using Darsy law $(\mathrm{Q}=\mathrm{Aki})$ (Chen, 2000), the permeability values of soil in the study is $\left(6.22 \times 10^{3} \_1.37 \times 10^{6} \mathrm{~cm} / \mathrm{sec}\right)$.

Engineering properties of soil in the study area: Two methods of finding soil bearing capacity are used which are: dynamic one which depends on ( $\mathrm{N}$-vales) in Standard Penetration Test (SPT) and static one that depends on direct shear test (Lafta et al., 2013).

First; dynamic method: The (N-vales) in each well in the study area (B.H 1-3) in different depths are (39-50/6), soil bearing value is $\left(6.9-41 \mathrm{ton} / \mathrm{m}^{2}\right)$ for depths $(1.5-20$ $\mathrm{m})$, depending on the equation (Tomlinson, 1993):

$$
\text { Qull }=\text { N/0.08(B+0.3)/B2(1+0.33Df } / B
$$

Second; Static method: We can find soil bearing capacity by using this mothed through direct shear test, cohesive value of soil (C) equals $\left(0-0 \mathrm{t} / \mathrm{m}^{2}\right)$ and values of internal friction angles are $\left(16-41^{\circ}\right)$ as shown in the following Table 4. Soil bearing capacity is calculated by the following suggested equation (Hansen, 1970; Kezdi, 1980):

$$
\text { Qull = CNc Sc dc }+q \text { Nq Sq dq }+1 / 2 B \gamma N \gamma S \gamma d \gamma
$$

From the results of (SPT) and direct shear test, it is clear that soil is (dense-very dense), the soil bearing capacity is increased with depth.

Chemical properties of soil: Chemical analysis for samples taken from wells in the study area of depths $(1.5-18 \mathrm{~m})$ is done according to the standards (BS-1377-1990 part 3 and ASTM Earth manual). Testing results as shown in Table 6 , show that $\mathrm{SO}_{3} \%$ is (4.55-9.11), $\mathrm{SO}_{3}$ is important because it reacts with cement components (Aluminum oxide) and resulted in gypsum and calcium sulfonate, the reactions will be accompanied by increasing in size which leads to cement extension and detrition (Lafta et al., 2013). Gypsum sediments are considered one of the most important source of sulfate, the continuing evaporation of gypsum water $\left(\mathrm{CaSo}_{4} 2_{2} \mathrm{H}_{2} \mathrm{O}\right)$ leads to $\left(\mathrm{CaSO}_{4}\right)$ sediments (Majeed, 2000), gypsum percentage is between 9.77-19.58 and has an effect on cement because $\mathrm{SO}_{4}$ is reacted with (slacked lime) $\mathrm{Ca}(\mathrm{OH})_{2}$ in cement to form crystal gypsum and the gypsum size extension effects and cracks the cement (Majeed, 2000). The percentage of TSS is $16.45-31.13$, salts change the void space among granules and work as one of the key compounds of strain (Lambe and Whitman, 1969). The percentage of organic materials is $0.26-1.58$ and it is possible to recognize soil that contains a high percentage of organic materials from its dark color, black or grey in addition to the smell of those organic materials (Terzaghi and Peck, 1974), the $(\mathrm{PH})$ percentage is between 7.8-8.1, $(\mathrm{Cl})$ is between (0.019-0.048\%), so, results show the increased percentage of $\left(\mathrm{Cl}\right.$ and $\left.\mathrm{SO}_{3}\right)$ and it is necessary to take the required procedures when building bases like using salt resisted cement and paint cement with materials that prevent salt water to go in.

Chemical analysis for ground water: Chemical analysis for ground water is done as stated in Table 7 and the analysis results show that water has weak basicity whether salts and $\mathrm{SO}_{4}$ have high percentage. 


\section{CONCLUSION}

Due to (USCS), it is clear that soil is coarsegranules (sandy) which is domineering, (SP), (SM), (SW), (SC) whether the soil is (ML to MH). N-vales in SPT is (39-50/6) and this shows the high density of soil in general and increased with depths for resistance the $(\mathrm{Cu})$ equals $\left(0-0 \mathrm{ton} / \mathrm{m}^{2}\right)$ internal vibration angle $(\varnothing)$ is $\left(16-41^{\circ}\right)$. The soil bearing capacity calculated by dynamic method is $\left(6.9-41.15 \mathrm{ton} / \mathrm{m}^{2}\right)$ for different depth while by using static method is $10.68-16.30 \mathrm{ton} / \mathrm{m}^{2}$. The depth of underground water from 7-12 m under (NGS).

Through, chemical analysis for ground water it is clear that water has weak basicity, there is high percentage of salts in general. The analysis also shows that soil contains a lot of gypsum and harmful quantities of $\mathrm{SO}_{4}$ that need to take the required procedures to protect the cement. The soil needs some of engineering works before construction and during making the base due to the above mentioned facts.

\section{APPENDIXES}

Appendixes 1: Physical properties and field test for soil for the residential complex project (BH1)

\begin{tabular}{|c|c|c|c|c|c|c|c|c|c|c|c|c|c|}
\hline \multirow{2}{*}{$\begin{array}{l}\text { Depth } \\
\text { (m) }\end{array}$} & \multirow{2}{*}{$\begin{array}{l}\text { Typey of } \\
\text { sample }\end{array}$} & \multicolumn{4}{|c|}{ Classification of soil } & \multirow{2}{*}{$\begin{array}{l}\text { Soil } \\
\text { description }\end{array}$} & \multicolumn{3}{|c|}{ Plasticity index } & \multicolumn{4}{|c|}{ Unit weight $\mathrm{gm} / \mathrm{cm}^{3}$} \\
\hline & & Clay (\%) & Silt (\%) & Sand (\%) & Grave (\%) & & MC (\%) & LL (\%) & PI (\%) & Dry & Bulk & GS & $\mathrm{SPT}(\mathrm{N})$ \\
\hline $0-0.5$ & DS & 6 & 28 & 66 & 0 & Yellowish whitish, very & - & - & - & - & - & - & - \\
\hline $1-1.5$ & DS & 2 & 27 & 71 & 0 & dense, fine to medium & - & - & - & - & - & 2.64 & - \\
\hline $2-2.5$ & SS & 3 & 25 & 72 & 0 & $\begin{array}{l}\text { silty sand soil with } \\
\text { gypsum content }\end{array}$ & - & - & - & 1.83 & 1.85 & -+ & 60 \\
\hline 3-3.5 & DS & 3 & 24 & 73 & 0 & Yellowish grayish, & - & - & - & - & - & 2.64 & - \\
\hline $4-4.5$ & SS & 4 & 27 & 69 & 0 & very dense, fine to & - & - & - & 2.05 & 2.06 & - & 67 \\
\hline $5-5.5$ & DS & 4 & 31 & 65 & 0 & medium to coarse & - & - & - & - & - & 2.64 & - \\
\hline 6-6.5 & DS & 7 & 28 & 65 & 0 & $\begin{array}{l}\text { silty sand soil with } \\
\text { gypsum content }\end{array}$ & - & - & - & - & - & - & - \\
\hline $7-7.5$ & SS & 26 & 18 & 56 & 0 & Reddish, very dense, & - & - & - & 2.15 & 2.17 & - & $50 / 4^{\prime \prime}$ \\
\hline 8-8.5 & DS & 27 & 19 & 54 & 0 & $\begin{array}{l}\text { fine, silty clayey } \\
\text { sand soil with } \\
\text { gypsum content, SC }\end{array}$ & - & 27.0 & 16.0 & - & - & 2.68 & - \\
\hline 9-9.5 & DS & 28 & 20 & 52 & 0 & Yellowish, very & - & - & - & - & - & - & - \\
\hline $10-10.5$ & SS & 28 & 17 & 55 & 0 & dense, fine, silty & 23.7 & - & - & 1.76 & 2.13 & - & $50 / 4^{\prime \prime}$ \\
\hline $11-11.5$ & DS & 31 & 16 & 53 & 0 & clayey sand soil & - & 29.0 & 20.0 & - & - & 2.68 & - \\
\hline $12-12.5$ & DS & 28 & 18 & 54 & 0 & with gypsum & - & - & - & - & - & - & - \\
\hline $13-13.5$ & SS & 25 & 16 & 59 & 0 & content , SC & 24.6 & - & - & 1.69 & 2.11 & - & $50 / 6^{\prime \prime}$ \\
\hline $14-14.5$ & DS & 5 & 21 & 71 & 3 & Yellowish, very & - & - & - & - & - & 2.64 & - \\
\hline 15-15.5 & DS & 2 & 18 & 75 & 5 & dense, fine to & - & - & - & - & - & - & - \\
\hline $16.5-17$ & SS & 2 & 18 & 76 & 4 & medium to coarse, & - & - & - & - & - & - & $50 / 5^{\prime \prime}$ \\
\hline $17.5-18$ & DS & 3 & 21 & 73 & 3 & silty sand soil with & 25.4 & - & - & - & - & 2.64 & - \\
\hline $18.5-19$ & DS & 2 & 24 & 70 & 4 & fine gravel and & - & - & - & 1.78 & 2.20 & - & - \\
\hline $19.5-20$ & SS & 2 & 21 & 73 & 4 & gypsum content & - & - & - & - & - & - & $50 / 3^{\prime \prime}$ \\
\hline
\end{tabular}

Appendixes 2: Physical properties \& field test for soil for the residential complex project (BH 2)

\begin{tabular}{|c|c|c|c|c|c|c|c|c|c|c|c|c|c|}
\hline \multirow{2}{*}{$\begin{array}{l}\text { Depth } \\
\text { (m) }\end{array}$} & \multirow{2}{*}{$\begin{array}{l}\text { Typey of } \\
\text { sample }\end{array}$} & \multicolumn{4}{|c|}{ Classification of soil } & \multirow{2}{*}{$\begin{array}{l}\text { Soil } \\
\text { description }\end{array}$} & \multicolumn{3}{|c|}{ Plasticity index } & \multicolumn{4}{|c|}{ Unit weight $\mathrm{gm} / \mathrm{cm}^{3}$} \\
\hline & & Clay (\%) & Silt (\%) & Sand (\%) & Grave (\%) & & MC (\%) & LL (\%) & PI (\%) & Dry & Bulk & GS & $\mathrm{SPT}(\mathrm{N})$ \\
\hline $0-1$ & DS & 7 & 21 & 72 & 0 & Yellowish whitish, & - & - & - & - & - & 2.64 & - \\
\hline $1.5-2$ & SS & 4 & 20 & 75 & 1 & $\begin{array}{l}\text { dense, fine to medium, } \\
\text { silty sand soil with } \\
\text { gypsum content }\end{array}$ & - & - & - & 1.84 & 1.85 & - & 39 \\
\hline $2.5-3$ & DS & 2 & 23 & 74 & 1 & Yellowish, very dense, & - & - & - & - & - & 2.64 & - \\
\hline $3.5-4$ & DS & 2 & 23 & 73 & 2 & fine to medium to & - & - & - & - & - & - & - \\
\hline 4.5-5 & SS & 5 & 26 & 67 & 2 & $\begin{array}{l}\text { coarse, silty sand soil } \\
\text { with gypsum content }\end{array}$ & - & - & - & 1.96 & 1.98 & - & 58 \\
\hline $5.5-6$ & DS & 25 & 22 & 53 & 0 & Reddish, very dense, & - & - & - & - & - & 2.68 & - \\
\hline $6.5-7$ & DS & 27 & 19 & 54 & 0 & fine, silty clayey sand & - & 27.0 & 16.0 & - & - & - & - \\
\hline $7.5-8$ & SS & 28 & 18 & 54 & 0 & soil (cementation ) with & - & - & - & 2.11 & 2.13 & - & $50 / 4^{\prime \prime}$ \\
\hline 8.5-9 & DS & 24 & 21 & 55 & 0 & gypsum content, SC & - & - & - & - & - & 2.68 & - \\
\hline $9.5-10$ & DS & 3 & 28 & 69 & 0 & Yellowish, very dense, & - & - & - & - & - & - & - \\
\hline $10.5-11$ & SS & 3 & 23 & 73 & 1 & fine to medium, silty & 26.2 & - & - & 1.65 & 2.06 & - & 83 \\
\hline $11.5-12$ & DS & 5 & 21 & 72 & 2 & soil, dense with & - & - & - & - & - & 2.64 & - \\
\hline $12.5-13$ & DS & 5 & 27 & 68 & 0 & gypsum content & - & - & - & - & - & - & - \\
\hline $13.5-14$ & SS & 24 & 22 & 54 & 0 & Greenish, very dense, & 24.6 & - & - & 1.73 & 2.16 & - & $50 / 4^{\prime \prime}$ \\
\hline $14.5-15$ & DS & 27 & 20 & 53 & 0 & fine, silty clayey sand & - & - & - & - & - & - & - \\
\hline $15.5-16$ & DS & 28 & 17 & 55 & 0 & soil, dense with high & - & 30.0 & 20.0 & - & - & 2.68 & - \\
\hline $16.5-17$ & SS & 26 & 17 & 57 & 0 & gypsum content, SC & 24.4 & - & - & 1.75 & 2.20 & - & $50 / 4^{\prime \prime}$ \\
\hline $17.5-18$ & DS & 6 & 21 & 69 & 4 & Yellowish, very dense, & - & - & - & - & - & - & - \\
\hline $18.5-19$ & DS & 2 & 19 & 75 & 4 & fine to medium to & - & - & - & & & 2.64 & - \\
\hline $19.5-20$ & SS & 2 & 20 & 73 & 5 & $\begin{array}{l}\text { coarse, silty sand soil, } \\
\text { dense with fine gravel } \\
\text { and gypsum content }\end{array}$ & - & - & - & - & - & - & $50 / 3^{\prime \prime}$ \\
\hline
\end{tabular}


J. Eng. Applied Sci., 14 (Special Issue 7): 10156-10161, 2019

Appendixes 3: Physical properties and field test for soil for the residential complex project (BH. 3)

\begin{tabular}{|c|c|c|c|c|c|c|c|c|c|c|c|c|c|}
\hline \multirow{2}{*}{$\begin{array}{l}\text { Depth } \\
\text { (m) }\end{array}$} & \multirow{2}{*}{$\begin{array}{l}\text { Typey of } \\
\text { sample }\end{array}$} & \multicolumn{4}{|c|}{ Classification of soil } & \multirow{2}{*}{$\begin{array}{l}\text { Soil } \\
\text { description }\end{array}$} & \multicolumn{3}{|c|}{ Plasticity index } & \multicolumn{4}{|c|}{ Unit weight $\mathrm{gm} / \mathrm{cm}^{3}$} \\
\hline & & Clay (\%) & Silt (\%) & Sand (\%) & Grave (\%) & & MC (\%) & LL (\%) & PI (\%) & Dry & Wet & GS & SPT (N) \\
\hline $0-0.5$ & DS & 5 & 18 & 77 & 0 & Yellowish whitish, & - & - & - & - & - & - & - \\
\hline $1-1.5$ & SS & 3 & 17 & 78 & 2 & very dense, fine to & - & - & - & 1.95 & 1.98 & - & 61 \\
\hline $2-2.5$ & DS & 3 & 20 & 76 & 1 & $\begin{array}{l}\text { medium, silty sand } \\
\text { soil with gypsum } \\
\text { content }\end{array}$ & - & - & - & - & - & 2.64 & - \\
\hline 3-3.5 & SS & 3 & 21 & 73 & 3 & Yellowish,very dense, & - & - & - & 1.83 & 1.85 & - & 73 \\
\hline $4-4.5$ & DS & 3 & 22 & 71 & 4 & fine to medium silty & - & - & - & - & - & 2.64 & - \\
\hline $5-5.5$ & DS & 2 & 27 & 67 & 4 & sand soil (cementation) & - & - & - & - & - & - & - \\
\hline $6-6.5$ & SS & 5 & 28 & 62 & 5 & $\begin{array}{l}\text { with gypsum content } \\
\text { and fine gravel }\end{array}$ & - & - & - & 2.5 & 2.6 & - & $50 / 5^{\prime \prime}$ \\
\hline $7-7.5$ & DS & 22 & 21 & 57 & 0 & Reddish, very dense, & - & - & - & - & - & 2.68 & - \\
\hline $8-8.5$ & DS & 24 & 22 & 53 & 1 & fine, silty clayey sand & - & 24.0 & 13.0 & - & - & - & - \\
\hline $9.5-10$ & SS & 27 & 18 & 55 & 0 & $\begin{array}{l}\text { soil with high gypsum } \\
\text { content, SC }\end{array}$ & 24.4 & - & - & 1.78 & 2.13 & - & $50 / 4^{\prime \prime}$ \\
\hline $10.5-11$ & DS & 42 & 22 & 36 & 0 & Reddish silty sandy & 17.3 & 39.0 & 21.0 & - & - & 2.70 & - \\
\hline $12-12.5$ & SS & 45 & 25 & 30 & 0 & $\begin{array}{l}\text { clay soil, very stiff } \\
\text { consistency with } \\
\text { content gypsum, CL }\end{array}$ & - & - & - & - & - & - & $50 / 5^{\prime \prime}$ \\
\hline 13-13.5 & DS & 29 & 19 & 52 & 0 & Yellowish, very dense, & - & - & - & - & - & - & - \\
\hline $14-14.5$ & DS & 27 & 18 & 55 & 0 & fine, silty clayey sand & - & 26.0 & 17.0 & - & - & 2.68 & - \\
\hline $15-15.5$ & SS & 27 & 17 & 56 & 0 & $\begin{array}{l}\text { soil with high gypsum } \\
\text { content, SC }\end{array}$ & 23.2 & - & - & 1.77 & 2.20 & - & $50 / 3^{\prime \prime}$ \\
\hline $16-16.5$ & DS & 4 & 24 & 70 & 2 & Yellowish, very dense, & - & - & - & - & - & 2.64 & - \\
\hline $17-17.5$ & DS & 2 & 21 & 75 & 2 & fine to medium, silty & - & - & - & - & - & - & - \\
\hline $17.5-18$ & SS & 3 & 21 & 75 & 1 & sand soil with & 25.6 & - & - & - & - & - & $50 / 5^{\prime \prime}$ \\
\hline 18.5-19 & DS & 4 & 23 & 71 & 2 & gypsum content & - & - & - & - & - & 2.64 & - \\
\hline $19.5-20$ & SS & 2 & 26 & 72 & 0 & & - & - & - & - & - & - & $50 / 4^{\prime \prime}$ \\
\hline
\end{tabular}

\section{REFERENCES}

AL-Jabban, W.J.M., 2014. Geotechnical assessment of Hilla City-Iraq. J. Univ. Babylon Eng. Sci., 22: 102-121.

Abood, M. Rashid, Al-Obaidy, A. Abdul Hameed and Qader et al., 2016. Geotachnique features of selected soil in Kirkuk City. Tikrit Mag. Pure Sci., 21: 97-105.

Al-Asho and U. Mohammed, 1997. Soil Mechanics Principles. University of Mosul, Mosul, Iraq, Pages: 574.

Al-Khalidy, A. Atya, Kadhum, N. Kadhum and Al-Suleiman et al., 2009. A study of soil techniques for sites of university buildings in university of qadisiya. Univ. Babylon, 1: 98-109.

Bell, F.G., 1994. The speeton clay of North Yorkshire, England: An investigation of its geotechnical properties. Eng. Geol., 36: 257-266.

Bowles, J.E., 1979. Physical and Geotechnical Properties of Soils. McGraw-Hill, New York, USA., ISBN:9780070661912, Pages: 478.

Bowles, J.E., 1984. Physical and Geotechnical Properties of Soils. McGrave Hill, Singapore, ISBN: 0070067724, Pages: 578.

Buday, T. and S.Z. Jassim, 1987. The Regional Geology of Iraq, Vol. 2, Tectonism, Magmatism and Metamorphism. Publication of the Geological Survey of Iraq, Baghdad, Iraq, Pages: 352.

Chen, F.H., 2000. Soil Engineering Testing, Design and Remediation. CRC Press, Boca Raton, Florida, ISBN:9780429126697, Pages: 288.

Hansen, J.B., 1970. A Revised and Extended Formula for Bearing Capacity. Danish Geotechnical Institute, Sweden.
Jassim, S.Z. and J.C. Goff, 2006. Geology of Iraq. Dolin, Prague and Moravian Museure, Brno, Czech Republic, Pages: 341.

Kezdi, A., 1980. HandBook of Soil Mechanics: Soil Testing. Elsevier, Amsterdam, Netherlands, ISBN:9780444997784,.

Lafta, A. Atya, Khalaf, M. Obaid and S. Al-Hadeethi, 2015. Geotachnique evaluation for selected soil in Al-Shanafiya City-Diwaniya province. Mag. Univ. Babylon Sci., 23: 1140-1178.

Lafta, A. Atya, Moyer and W. Jasem, 2013. Studying some of physical, engineering and chemical features of selected soil of a site for university buildings in University of Babylon. J. Babylon Univ. Eng. Sci., 21: 791-824.

Lambe, T.W. and R.V. Whitman, 1969. Soil Mechanics. John Wiley \& Sons, Hoboken, New Jersey, USA., ISBN:9780852265031, Pages: 553.

Majeed, A.H., 2000. Engineering characteristics of gypseous soils. Ph.D Thesis, College of Engineering, Department of Civil Engineering, University of Baghdad, Baghdad, Iraq.

Terzaghi, K. and R.B. Peck, 1974. Soil Mechanics in Engineering Practice. 2nd Edn., John Wiley and Sons, Hoboken, New Jersey, USA., Pages: 72.

Thabet, K. Mohammed, Al-Asho and M. Umer, 1993. Geology Rules for Engineers. University of Mosul, Mosul, Iraq, Pages: 338.

Tomlinson, M.J., 1993. Pile Design and Contrution Practice. 4th Edn., E and FN SPON, London, New York, USA., ISBN:9780203474570, Pages: 411.

Yasin, M.J., 1990. Some geotechnical properties of soils in the Haditha Area, W. Iraq. Bull. Intl. Assoc. Eng. Geol., 41: 129-36. 